\title{
Combination of Trichoderma viride and Pseudomonas fluorescens for the enhanced control of Fusarium wilt disease caused by Fusarium oxysporum infecting Arachis hypogaea L.
}

\author{
P. Rajeswari \\ Department of Botany, University of Delhi, Delhi -110007 , India \\ E-mail: aksharaasmitha@gmail.com
}

\section{Article Info}

DOI:10.31018/jans.v11i1.1985 Received: January 9, 2019 Revised: February 15, 2019 Accepted: February 18, 2019

\begin{abstract}
Fusarium wilt caused by Fusarium oxysporum is a devastating disease of peanut. The fungus causes severe yield loss in groundnut. Combinations of biocontrol agents that are compatible with each other is a viable approach to control the plant disease. The study was conducted to determine the beneficiary aspects of combining different species of Trichoderma and Pseudomonas fluorescens i.e Trichoderma viride+Pseudomonas fluorescens $(T v+P f)$, Trichoderma harzianum $+P$ seudomonas fluorescens $(T h+P f)$ and Trichoderma viride +Trichoderma harzianum $(T v+T h)$ to control the Fusarium wilt in biochemical parameters such as DNA, RNA, Amino nitrogen, phenols, dihydroxy and proline contents of Arachis hypogaea L. Among the three combinations tested, Trichoderma viride + Pseudomonas fluorescens $(1+2 \%)$ sprayed leaves provided greater suppression of Fusarium oxysporum by increasing the levels of DNA, RNA, Amino nitrogen contents resulting in the suppression of Fusarium wilt disease of Arachis hypogaea L. Maximum reduction of DNA, RNA, Amino nitrogen was observed in the infected Fusarium oxysporum leaves Phenol, Dihydroxy phenols and proline contents increase sharply in the treated plants treated with $(T v+P f)$ as compared to the control plants. At the same time the other two combinations resulted in enhanced control in comparison with individual ones. This present study indicates that specific combination of Trichoderma viride and Pseudomonas fluorescens could have the greater efficacy in the inhibition of pathogen in the biocontrol of Fusarium wilt disease as compared with individual strains.
\end{abstract}

Keywords: Arachis hypogaea L., Fusarium wilt, Trichoderma viride, Trichoderma harzianum, Pseudomonas fluorescens

\section{INTRODUCTION}

Groundnut (Arachis hypogaea L.) is the most versatile legume and important oil seed crop grown worldwide. Grover (1981) documented that more than 55 pathogens were causing damage to ground nut crop. The crop improves soil fertility through the fixation of atmospheric dinitrogen into the soil and reducing to synthetic nitrogen fertilizers required. (Dakora et al., 1987; Mokgehle et al., 2014). Ground nut is the fourth largest edible oil crop in the world. (Shilman et al., 2011) Fusarium oxysporum is the causal agent of vascular wilt disease that affects large variety of economically important plants (Beckman 1987). Fusarium wilt disease caused by Fusarium oxysporum (Schlecht. Emend.Snyder and Hansen) is a damaging disease which causes considerable yield loss in groundnut. The fungus invades through roots and causes complete loss in yield, when occurs at vegetative and reproductive stages of crop. (Navas et al., 2000).

Infection by pathogen interferes with host nucleic acids and protein metabolism especially enzymes. Padma Singh (2000) reported that disruption of cell structure coupled with enhanced proteolytic enzyme activity results in enhanced disease and decreased nitrogen content in the Alternaria sp. onion infected leaves. Duthie et al (2003); Fraga et al (2010) studied that phenolic compounds are produced by plants as secondary metabolites participating in growth, lignification, pigmentation, pollination, and resistance against pathogens, predators, and environmental stresses They also participate in oxidation -reduction reactions , in the inhibition of production of cell wall degrading enzymes by the pathogen and involved in stimulation of auxin activity. (Mandavia et al., 2003). Proline is a proteinogenic amino acid and is essential for primary metabolism (Szabados and Savoure 2009; Verslues and Sharma 2010). Dar et al (2016) reported that Proline accumulation occurs under various kinds of environmental stresses in many plant species.Earlier studies demonstrated successfully that Trichoderma spp. and Pseudomonas fluorescens have been con- 
sidered as the most effective antagonistic microbes in biocontrol of Fusarium wilt (Sharavanan et al. 2003). Kemerait Jr. (2000) evaluated the pathogenicity of soil borne fungi associated with groundnut. The strains of Trichoderma spp. produces cell wall degrading enzymes, antibiotics and also many types of secondary metabolites the role of which has been established in biocontrol activity. Woo and Lorito (2007) demonstrated that a strain of $T$. harzianum produced different secondary metabolites that could further focus on the inhibiting the pathogen invasion infecting that plant. Alabouvette et al. (2009) reported that the success of biological control depends not only on the mode of action of biocontrol agents but also on protective effects of BCA'S in targeting the pathogen to improve the production, formulation and application processes. Talaviya and Jadega (2015) reported that combined application of $T$. viride+ $T$. harzianum+ Pseudomonas fluorescens was significantly effective in controlling cumin wilt disease and improves higher yield. Rajeswari and Kapoor (2017) reported that the combination of Trichoderma viride and Pseudomonas fluorescens is effective in managing the Fusarium wilt disease in Arachis hypogaea $\mathrm{L}$ as compared to single strains. Zhang et al. (2008) has established combined application of Basillus sutilis SQR-5 and Paenibacillus polymyxa SQR-21 is beneficial in control of Fusarium wilt disease in cucumber plants. Wu et al. (2009) studied that combinations of antagonistic microorganisms (Paenibacillus polymyxa and Trichoderma harzianum) had a greater efficacy to suppress Fusarium wilt of watermelon. Somasekhara et al. (1996) reported that different species of Trichoderma i.e T. viride, T.harzianum and T.hamatum are effective in controlling F.oxysporum F.sp.udum. in pigeon pea wilt. Nikam et al. (2007) established that $T$. viride showed maximum growth inhibition of $F$. oxysporum f.sp.ciceri. Najar et al. (2011) evaluated the efficacy of Trichoderma viride, Trichoderma harzianum and Pseudomonas fluorescens in the inhibition of Fusarium solani f.sp. melongenae causing wilt of Brinjal.The present work was taken to determine that whether specific interactions of Trichoderma species and Pseudomonas fluorescens influence the suppression of Fusarium wilt disease by combination of these biocontrol agents on Arachis hypogaea L. as compared to individual strain.

\section{MATERIALS AND METHODS}

Microbial cultures: Trichoderma viride, Trichoderma harzianum, Pseudomonas fluorescens and Fusarium oxysporum cultures used in this study were obtained from Institute of Microbial Technology (IMTECH, Chandigarh. MTCC Nos 2047, 3112, 664. 2087, respectively). Fusarium oxysporum was cultured on Potato Sucrose Agar
(PSA) for 30 days. Trichoderma viride and Trichoderma harzianum were grown on Malt Extract Agar (MA) .Pseudomonas fluorescens was cultured on Antartic biotic Medium (ABM) for 30 days. The above mentioned cultures further grown on Czapek's medium separately for 7 days at $28^{\circ}$ $\pm 0.2 \mathrm{C}$. After the centrifugation culture filtrates were taken.

Plant material: The plants of Arachis hypogaea (JLR -variety) were grown up to 75 DAS in twenty earthen pots $(25 \mathrm{~cm}$ diameter)and grouped into three sets- control, infected and infected treated. The first set of four pots as control plants was sprayed with distilled water (sample 1). The second set of four pots as infected plants were sprayed with culture of pathogen, Fusarium oxysporum on 30 DAS and left without any treatment (sample 2). The third set of twelve pots marked as infected treated was sprayed with pathogen on 30 DAS and these infected plants were sprayed with OIC of culture filtrates of combinations of biocontrol agents, Trichoderma spp. and Pseudomonas fluorescens: Trichoderma viride + Pseudomonas fluorescens $(T v+P f)(1+2 \%)$ as sample 3 , Trichoderma harzianum + Pseudomonas fluorescens $(T h+P f)(1.5+2 \%)$ as sample 4 , and Trichoderma viride + Trichoderma harzianum $(T v+T h)(1+1.5 \%)$ as sample 5 on 40 DAS. The leaves of control, infected and infected treated plants were collected on 50 DAS for estimating the biochemical parameters.

DNA estimation: In DNA estimation, the method of Burton (1956) was used. To $1.5 \mathrm{ml}$ of PCA extract, $3 \mathrm{ml}$ of diphenylamine reagent was added. The tubes were kept at $70^{\circ} \mathrm{C}$ in a boiling water bath for $20 \mathrm{~min}$ and then cooled. The colour development was read at $600 \mathrm{~nm}$ on a Spectrophotometer. A Standard calibration curve was prepared by using known concentration of calf thymus DNA. The DNA content was expressed in $\mathrm{mg}$ DNA/g fresh weight of the leaf tissue.

Estimation of RNA: RNA was estimated by using the method of Rawal et al. (1977). To the $0.5 \mathrm{ml}$ nucleic acid fractions, $3 \mathrm{ml}$ of orcinol reagent was added. The tubes containing the mixture were kept in water bath for $20 \mathrm{~min}$ at $90^{\circ} \mathrm{C}$ and then cooled. The colour that was produced was measured at $665 \mathrm{~nm}$ in Spectrophotomer. By taking the known concentration of purified RNA the standard curve was prepared.

Estimation of aminonitrogen: Amino nitrogen was estimated by using the method of Levine and Chargoff (1951).

The $\mathrm{pH}$ of the alcoholic extract was adjusted to 7.0 by adding $0.1 \mathrm{~N} \mathrm{NaOH} / \mathrm{HC} 1$.To $1 \mathrm{ml}$ of the above extract $1 \mathrm{ml}$ of ninhydrin reagent was added. The tubes was heated for $20 \mathrm{~min}$ and cooled. To the above mixtire, $5 \mathrm{ml}$ of methyl cellosolve was added and the absorbance was read at $570 \mathrm{nrn}$ in Systronics Spectrophotometer. 
Estimation of total phenol: The method of Bray and Thorpe (1954) was used for Total phenol estimation. $1 \mathrm{ml}$ of alcoholic extract was taken in the test tube. To this, $1 \mathrm{ml}$ of Folin-Ciocalteau reagent and $2 \mathrm{ml}$ of $20 \%$ sodium carbonate were added and shaken well. The above mixture was heated in a boiling water bath for $1 \mathrm{~min}$ and cooled under running tap water. The blue colour solution formed was diluted to $25 \mathrm{ml}$ with distilled water and read at $650 \mathrm{~nm}$ in Systronics Spectrophotometer. Total phenols were calculated using a standard curve catechol as standard.

Estimation of ortho Di-hydroxy phenols: Ortho Di-hydroxy phenols was estimated by the method proposed by Johnson and Shoal (1952) was used. $1 \mathrm{ml}$ of alcoholic extract was taken in the test tube. To this, $1 \mathrm{ml}$ of $0.5 \mathrm{~N} \mathrm{HCl}$ and $1 \mathrm{ml}$ of Arnow's reagent was added. To the above mixture $2 \mathrm{ml}$ of $1 \mathrm{~N} \mathrm{NaOH}$ and $10 \mathrm{ml}$ of distilled water were added. $\mathrm{NaOH}$ was added slowly. The pink colour appears and the colour intensity was reduced by diluting it to $25 \mathrm{ml}$ with distilled water and the absorbance read at $515 \mathrm{~nm}$. Standard curve was prepared using catechol as standard.

Estimation of proline: Proline extraction and estimation was done according to the method of Bates et a1 (1973).Fresh plant material was homogenized with $10 \mathrm{ml}$ of $3 \%$ aqueous sulfosalicylic acid. The homogenate was filtered through Whatman No. 2 filter paper. The residue was re -extracted 3 to 4 times. The extracts were pooled

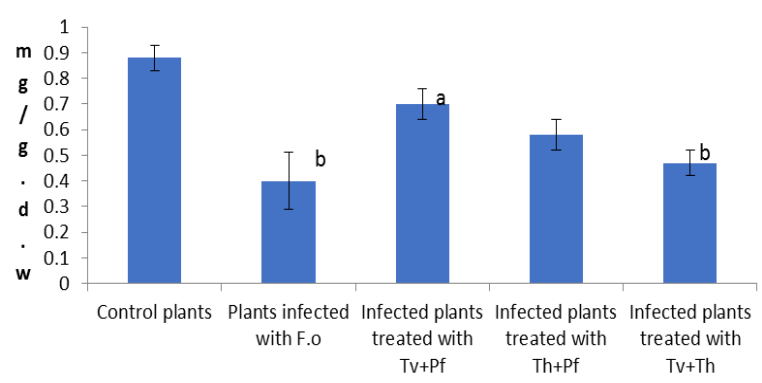

Fig. 1. Effect of culture filtrates of $T$. viride $+P$. fluorescens, $T$. harzianum $+P$. fluorescens and T.viride + T. harzianum on Amino nitrogen content of Arachis hypogaea leaves infected with $F$. oxysporum. ${ }^{a} p<$ 0.001 as compared to control, ${ }^{b} p<0.01$ as compared to control; Values within column followed by different letters are significantly different according to Tukey's HSD multiple range test (TMRT) at 5\% level of significance $(n=3)$. and made up to $20 \mathrm{ml}$ with aqueous sulfosalicylic acid and used for the estimation.

$2.0 \mathrm{ml}$ of the above filtrate was taken in the test tube. To this, $2.0 \mathrm{ml}$ of acid ninhydrin and $2.0 \mathrm{ml}$ of glacial acetic acid was added. The mixture containing tubes were incubated for $1 \mathrm{~h}$ at $100^{\circ} \mathrm{C}$ on a water bath. The tubes were transferred on ice to terminate the reaction After that $4.0 \mathrm{ml}$ of toluene was added and shaken vigorously for $15-20$ seconds. The chromophore containing toluene was aspirated from the aqueous phase It was allowed to reach room temperature and the absorbance measured at $575 \mathrm{~nm}$. By taking the known concentrations of Proline standard curve was prepared.

\section{RESULTS AND DISCUSSION}

In this study among the three combinations of Trichoderma spp and Pseudomonas fluorescens, Trichoderma viride and Pseudomonas fluorescens $(1+2 \%)$ was found significantly effective in increasing the DNA, RNA, and Amino nitrogen content of the leaves. This study confirms to the earlier findings of Rudresh et al. (2005) that the combined inoculation of Rhizobium spp with Trichoderma spp resulted in increased growth, nutrient uptake and yield of chickpea. John et al. (2010) found that soybean plants treated with Trichoderma viride showed higher total nitrogen, carbon and dry weight and established the enhancement

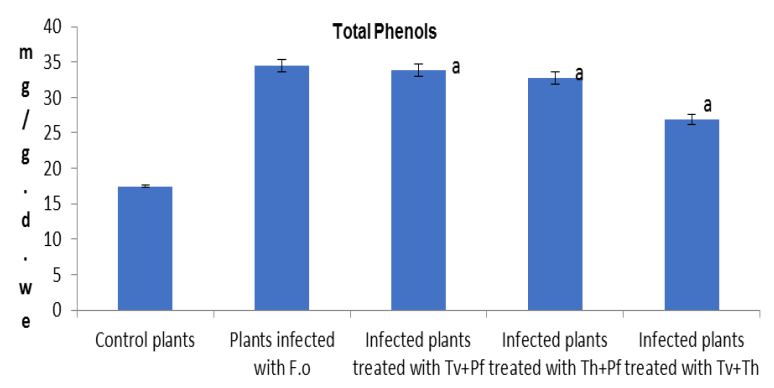

Fig. 2. Effect of culture filtrates of $T$. viride+P.fluorescens, T. harzianum $+P$.fluorescens and T.viride $+T$. harzianum on Total phenols content of Arachis hypogaea leaves infected with F.oxysporum. ${ }^{a} p<0.001$ as compared to control; Values within column followed by different letters are significantly different according to Tukey's HSD multiple range test (TMRT) at $5 \%$ level of significance $(n=3)$.

Table 1. Effect of culture filtrates of T.viride+P.fluorescens, T.harzianum+P.fluorescens and T.viride $+T$. harzianum on DNA and RNA content of Arachis hypogaea leaves infected with F.oxysporum. ${ }^{a} p<0.001$ as compared to control; Values within column followed by different letters are significantly different according to Tukey's HSD multiple range test (TMRT) at $5 \%$ level of significance $(n=3)$

\begin{tabular}{lcc}
\hline Treatments & DNA (mg/g.f.w) & RNA(mg/g.f.w) \\
\hline Control plants & $33.93 \pm 0.34$ & $48.39 \pm 0.34$ \\
Plants infected with F. oxysporum & $6.42 \pm 0.0 .34^{\mathrm{a}}$ & $12.24 \pm 0.35^{\mathrm{a}}$ \\
Infected plants treated with T.viride $+P$. fluorescens & $26.90 \pm 0.0 .34^{\mathrm{a}}$ & $24.49 \pm 0.34^{\mathrm{a}}$ \\
Infected plants treated with T. harzianum+P.fluorescens & $18.47 \pm 0.34^{\mathrm{a}}$ & $17.06 \pm 0.34^{\mathrm{a}}$ \\
Infected plants treated with T.viride+ T. harzianum & $17.20 \pm 0.34^{\mathrm{a}}$ & $16.66 \pm 0.34^{\mathrm{a}}$ \\
\hline \hline
\end{tabular}


Rajeswari, P. / J. Appl. \& Nat. Sci. 11(1): 138-143 (2019)

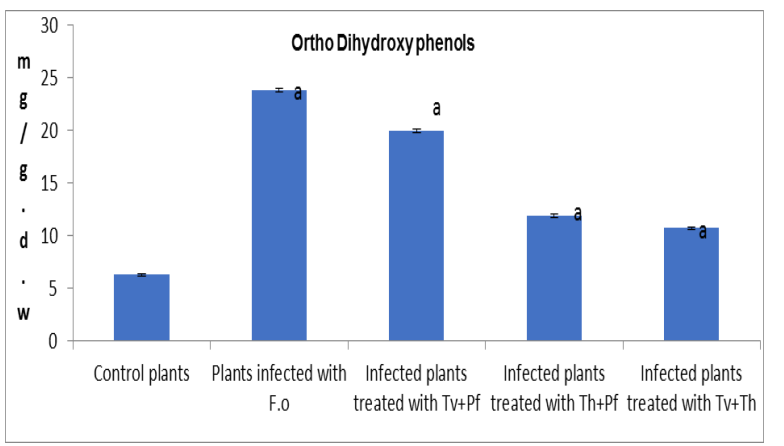

Fig. 3. Effect of culture filtrates of $T$.viride $+P$.fluorescens, T.harzianum $+P$.fluorescens and T.viride $+T$. harzianum on orthro dihydroxy content of Arachis hypogaea leaves infected with F.oxysporum. ${ }^{a} p<0.001$ as compared to control; Values within column followed by different letters are significantly different according to Tukey's HSD multiple range test (TMRT) at 5\% level of significance $(n=3)$.

of plant growth compared with the plants infected with Pythium arrhenomanes and Fusarium oxysporum f.sp. adzuki .

Results revealed that 3 -fold increase in phenol, dihydroxy and proline contents in Fusarium oxysporum infected leaf compared to control. (Fig 2,3,4). De Ascensao and Dubery (2003) studied the changes over time in specific phenolic compounds in banana in response to the pathogen $F$. oxysporum $f$. sp. cubense. They reported that induced phenolics included coumaric, ferulic, sinapic and vanillic acid. These are cell wall bound phenolics esterified to the cell wall and cross link to form lignin-like polymers reinforcing the cell wall in order to provide defense against the invading pathogen.

Panina et al. (2007) also observed the changes in phenolic compounds in leaves after exposing roots to Fusarium oxysporum. This indicates that the response is truly systemic and that the physiological state of the tomato plant has been altered. This is in agreement with reports of increase and decrease in tomato phenolics in response to other biotic and abiotic stressors (Tamietti et al., 1993; Di'az et al., 2005; Cavalcanti et al., 2006). Ojha and Chatterjee (2012) observed that the phenol content was significantly higher in F. oxysporum infected tomato plants. Induction of total phenol ac -cumulation in the host plant treated with salicylic acid and Trichoderma harzianum could play an vital role in resistance and defense against $F$. oxysporum. Similar findings was made by (Alstrom $1995)$ that the higher phenol content due to Pseudomonas treatment in tomato plant infected with $P$. syringe. Beckman (2000) has pointed that the importance of phenolic compounds could play a

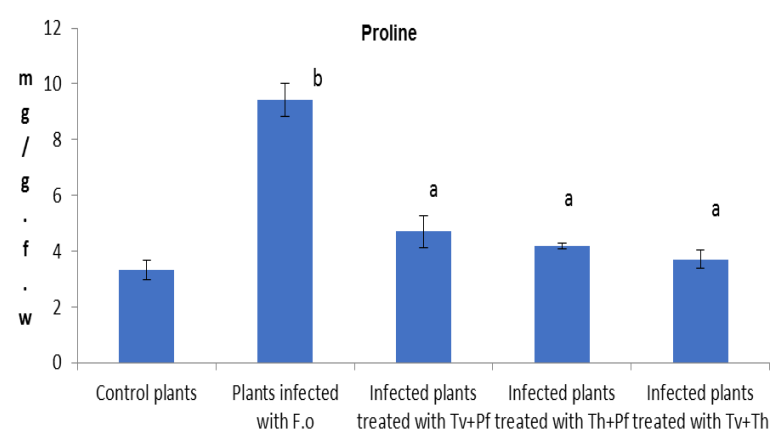

Fig. 4. Effect of culture filtrates of T.viride+P.fluorescens, T.harzianum+P.fluorescens and T.viride $+T$. harzianum on proline content of Arachis hypogaea leaves infected with F.oxysporum. ${ }^{a} p<0.001$ as compared to control, ${ }^{b} p<0.01$ as compared to control; Values within column followed by different letters are significantly different according to Tukey's HSD multiple range test (TMRT) at $5 \%$ level of significance $(n=3)$.

major role in host defence pathways and in signalling for host defences rather than their toxicity to the pathogen in reducing the wilt disease.

Combination of biocontrol agents with different mechanisms of disease control will have an beneficial effects and results in enhanced disease control compared to their individual ones (Guetsky et al., 2002). Results also illustrated that leaves sprayed with combinations of Trichoderma harzianum and Pseudomonas fluorescens $(T h+P f)$ and Trichoderma viride and Trichoderma harzianum $(T v+T h)$ were significantly effective in increasing the amount of DNA, RNA, Amino nitrogen content when compared to individual strains.(Table1,Fig1) Phenols, Dihydroxy and proline contents were also significantly increased in the treated leaves. (Fig 2,3.4). Present study reveals that among the three combinations of Trichoderma spp and Pseudomonas fluorescens, a significant combination of Trichoderma viride and Pseudomonas fluorescens $(T v+P f)(1+2 \%)$ was found to have greater efficacy than other two combinations in the control of Fusarium wilt in Arachis hypogaea L. The study substantiates the findings of Hoda et al (2016) who established that the combined application of Pseudomonas fluorescens, Bacillus subtilus and Rahnella aquatilis have potential benefits in the enhanced suppression of black leg of potato. Similar findings was made by Manjula et al. (2004) Pseudomonas fluorescens combined with Trichoderma viride has improved the biocontrol activity against stem rot in groundnut.

\section{Conclusion}

Pathogenecity suppression of Fusarium oxysporum by the compatible combination of Trichoderma viride +Pseudomonas fluorescens $(1+2 \%)$ was significantly better compared to the other two combinations. This enhanced control of 
the disease by the combinations of biocontrol agents could be possible by different mechanisms i.e mycoparasitism, spacial and nutrient competition, production of antibiotics and volatile compounds compared to individual ones. The present study concluded that specific interactions of biocontrol agents could influence the suppression of Fusarium wilt disease by combination of these bioagents.

\section{ACKNOWLEDGEMENTS}

I am thankful to University Grant Commission (UGC) , India for funding and to pursue the research under the category of Post-Doctoral Fellowship for Women. My sincere thanks to my mentor Prof. Rupam Kapoor, Department of Botany, University of Delhi for her support.

\section{REFERENCES}

1. Alstrom,S. (1995). Evidence of disease resistance induced by rhizosphere Pseudomonad against Pseudomonas syringae pv.phaseolicola.J.Gen. Appl. Microbiol. 41:315-325

2. Alabouvette, Claude., Olivain, Chanta., Migheli,Quirico.,and Steinberg, Christian. (2009). Microbiological control of soil-borne phytopathogenic fungi with special emphasis on wilt-inducing Fusarium oxyporum. New Phytol. 184:529-544

3. Beckman,C.H. (2000). Phenolic-storing cells: keys to programmed cell death and periderm formation in wilt disease resistance and in general defense responses in plants. Physiol. Mol. Plant Pathol, 57101-110

4. Bates,S., Waldren, R..P and Teare, I. D . (1973). Rapid determination of free proline for water stress studies.Plant and Soil,39: 205-208

5. Beckman, C.H. (1987) The nature of wilt diseases in plants. Amer. Phytopathol. Soc. St, Paul MN., USA. 1175pp

6. Bray, H.G and Thorpe, W.V. (1954). Analysis of phenolic compounds of interest in metabolism. Meth. Biochem. Anal. $1: 27-52$

7. Burton,A.J. (1956) The study of the conditions and mechanism of the diphenylamine reaction for the colorimetric estimation of DNA. Biochem. J.,62:315323

8. Cavalcanti, F.R.,Resende,M.L.V.,Carvalho,C.P.S., Silveira,J.A.G.andOliveiraJ.T.A.(2006). Induced defense responses and protective effects on tomato against Xanthomonas vesicatoria by aqueous extract from Solanum lycocarpum infected with Crinipellis perniciosa. Biol. Control, 39:408-417.

9. Dakora, F.D., Aboyinga , R.A., Mahama,Y.and Apaseku,,J.(1987). Assessment of N2 fixation in groundnut (Arachis hypogaea L.) and cowpea (Vigna unguiculata $\mathrm{L}$. Walp) and their relative $\mathrm{N}$ contribution to a succeeding maize crop in Northern Ghana. Mircen, Journal of Applied Microbiology and Biotechnol. 3:389-399

10.Dar, Mudasir Irfan., Mohd Irfan, Naikoo., Farha, Rehman., Fauzia, Naushin., and Fareed, Ahmad Khan . (2016). Proline accumulation in Plants: Roles in Stress Tolerance and Plant Decelopment In Osmolytes and Plants Acclimation to Changing Environment: Emerging Omics Technologies, pp-155-166
11.De Ascensao, A.R.F.D.C and Dubery, I,A. (2003). Soluble and wall-bound phenolics and phenolic polymers in Musa acuminata roots exposed to elicitors from Fusarium oxysporum f. sp. cubense. Phytochem., 63:679-686

12.Di'az,J., Silvar,C., Varela,M.M., Bernal, A and Merino,F. (2005). Fusarium confers protection against several mycelial pathogens of pepper plants. Plant Pathol., 54:773-780

13.Duthie G.G., Gardner, P.T., Kyle ,J.A. (2003). Plant polyphenols: are they the new magic bullet. Proc Nutr Soc., 62: 599-603

14.Fraga, C.G., Galleano, M., Verstraeten, S.V and Oteiza, P.I. (2010) Basic biochemical mechanisms behind the health benefits of polyphenols. Mol Aspects Med., 31:435-445

15.Grover, R.K . (1981). Present state of research and future trends in controlling diseases of oilseeds and pulses, In: PAI National Seminar on Increasing of Pulses and Oilseeds Production Through Plant Protection, (Vigyan Bhavan,NewDelhi ) 315 pp.

16.Guetsky, R., Stienberg, D., Elad, Y., Fischer, E. and Dinoor, A. (2002). Improving biological control by combining biocontrol agents each with several mechanisms of disease suppression. Phytopathol,, 92: 976 $-985$

17. Hoda, H., El- Hendaway, Kamal A.and Abou Elyousr, M (2016). Combination of Different antagonistic bacteria to control of potato black leg disease caused by Pectobacterium atrosepticum under greenhouse and field conditions. Int. J. Phytopatol., 5:35-43

18.John, Rojan P.,Tyagi,R.D., Prévost,D.,Brar, Satinder K., Pouleur, Stéphan.and Surampalli,R.Y (2010) Mycoparasitic Trichoderma viride as a biocontrol agent against Fusarium oxysporum $f$. sp. adzuki and Pythium arrhenomanes and as a growth promoter of soy bean. Crop Prot.,29:1452-1459.

19.Johnson, G. and Shoal, L. A. (1952). Relation of Chlorogenic acid to scab resistance in potatoes. Science, 115: 627-629.

20.Kemerait Jr Robert Chester (2000) A Characterization of Soil borne Fungi Associated With Peanut (Arachis hypogaea L.), Doctoral dissertation submitted to University of Florida.

21.Levine, C and Chargaff, E (1951) Procedures for the micro estimation of nitrogenous phosphatide constituents. J. Biol. Chem., 192(2):465-479.

22.Mandavia, M.K., Gajera, H.P.,Khan,N.A. and Parameswaran,M.(2003) Inhibitory action of phenolic compounds on cell wall degrading enzymes: host pathogen interaction in Fusarium wilt of cumin. Indian J. Agri. Biochem, 16:39-42.

23.Manjula, K., Krishna Kishore, G., Girish, A. G. and Singh, S. D. (2004)Combined application of Pseudomonas fluorescens and Trichoderma viride has improved the biocontrol activity against stem rot in groundnut.Plant Pathol., J, 20:75-80.

24.Mokgehle, S. N., Dakora, F.D.and Mathews, C. (2014) Variation in N2 fixation and N contribution by 25 groundnut (Arachis hypogaea L.) varieties grown in different agro-ecologies, measured using $15 \mathrm{~N}$ natural abundance, Agriculture, Ecosystems and Environ., 195: 161-172.

25.Najar, A.G., Anwar,Ali., Masoodi, Lubna. and Khar, M.S. (2011)Evaluation of native biocontrol agents against Fusarium solani f.sp.melongenae causing wilt disease of Brinjal in Kashmir. J. Phytol., 3 :31-34. 
26.Navas-Cortes, J.A., Hau, B. and Jimenez-Diaz, R.M (2000) Yield loss in chickpea in relation to development to Fusarium wilt epidemics. Phytopathol., 90: 1269-1278.

27.Nikam, P.S., Jagtap, G.P. and Sontakke, P.L. (2007) Management of chickpea wilt caused by Fusarium oxysporum f. sp. cicero. Afri. Jour. Agri. Res., 2: 692697

28.Ojha, Suprakash and Chatterjee,NarayanChandra. (2012). Induction of resistance in tomato plants against Fusarium oxysporum f.sp. lycopersici mediated through salicylic acid and Trichoderma harzianum. J. Plant Prot. Res, .52: 220-225

29.PadmaSingh (2000). Permeability changes and mineral metabolism in the leaves of onion infected with Alternaria porri.Ad. Plant Sci., 13 :323-325

30.Panina,Y., Fravel, D.R., Baker, C.J.and Shcherbakova, L. A. (2007). Biocontrol and plant pathogenic Fusarium oxysporum-induced changes in phenolic compounds in tomato leaves and roots.J. Phytopathol.,155: 475-481

31.Rajeswari, P and Rupam Kapoor (2017). Combined application of different species of Trichoderma and Pseudomonas fluorescens on the cellulolytic enzymes of Fusarium oxysporum for the control of Fusarium wilt disease in Arachis hypogaea. Biosciences, Biotechnology, Research As.i, 14:1169-1176

32.Rudresh,D.L, Shivaprakash,M. K.and Prasad R.D. (2005). Effect of combined application of Rhizobium, phosphate solubilizing bacterium and Trichoderma spp. on growth, nutrient uptake and yield of chickpea (Cicer aritenium L.). Applied Soil Ecol., 28 :139-146

33.Rawal, V.M., Patel,U.S., Rao , G.N. and Desai,R .R . (1977). Chemical and biochemical studies on cataracts and human lenses III. Quantitative study of proteins, RNA and DNA. Arogya. J. Health Sci.,69-75

34.Sharavanan, T., Muthusamy, M. and Marimuthu, T. (2003) Development of integrated approach to manage the Fusarial wilt of banana. Crop Protect., 22: $1117-1123$
35.Shilman ,F., Brand ,Y., Brand, A., Hedvat, I., Hovav,R. (2011) Identi cation and molecular characterization of homeologous $\Delta 9$-stearoyl acyl carrier protein desaturase 3 genes from the allotetraploid peanut (Arachis hypogaea). Plant Molecular Biology Reporter, 29 : 232-241

36.Somasekhara,Y.M., Anilkumar,T.B and Siddara,A.H (1996). Biocontrol of pigeonpea wilt Fusarium udum. Mysore J. Agric. 30: 159-163

37.Szabados, L.and Savoure, A. (2009). Proline: a multifunctional amino acid. Trends Plant Sci,15:89-97

38.Talaviya,J.and Jadeja, K.B. (2015)Efficacy of bioagents alone and in combination microbial population against the wilt incidence of cumin. Journal of Biological cont, 29: 162- 166.

39.Tamietti,G., Ferraris,L., Matta. and Gentile,I.A. (1993)Physiological responses of tomato plants grown in Fusarium suppressive soil,J. Phytopathol, $138: 66-76$.

40.Verslues, P.Eand Sharma, S. (2010). Proline metabolism and its implications for plant-environment interaction. Arabidopsis Book 8 e0140.

41.Woo,S.L.and Lorito,M. (2007). Exploiting the interactions between fungal antagonists, pathogens and the plant for biocontrol, In: Vurro M, Gresel J, eds. Novel biotechnologies for biocontrol agent enhancement and management. Dordrecht, the Netherlands: Springer, 107-130.

42.Wu,Hong-sheng.,Yang,Xin-ning.,Fan,Jiaqin.,Miao,Wei-guo., Ling, Ning., Xu,Yang-chun., Huang,Qi-wei and ShenQirong.(2009). Suppression of Fusarium wilt of watermelon by a bio-organic fertilizer containing combinations of antagonistic microorganisms. Biocontr., 54 :287-300.

43.Zhang,Shusheng., Raza,Waseem.,Yang,Xingming.,H u,Jiang.,Huang, Qiwei.,Xu,Yangchun., Liu,Xinghai., Ran,Wei. andShen,Qirong. (2008). Control of Fusarium wilt disease of cucumber plants with the application of a bio-organic fertilizer. Biol. Fertil. Soils, 44 :1073-1080. 